Article

\title{
Contextual Factors Affecting the Innovation Performance of Manufacturing SMEs in Korea: A Structural Equation Modeling Approach
}

\author{
Ye Seul Choi (1) and Up Lim * \\ Department of Urban Planning and Engineering, Yonsei University, 50 Yonsei-ro, Seodaemun-gu, \\ Seoul 03722, Korea; yeseul.choi@yonsei.ac.kr \\ * Correspondence: uplim@yonsei.ac.kr; Tel.: +82-2-2123-5897
}

Received: 17 March 2017; Accepted: 1 July 2017; Published: 6 July 2017

\begin{abstract}
This study empirically explores the relationship between innovation performance and the internal and contextual factors driving technological innovation in manufacturing small and medium-sized enterprises (SMEs) in metropolitan areas of Korea using structural equation modeling (SEM). Our analysis is based on firm-level data from the Korean Innovation Survey conducted by the Science and Technology Policy Institute in 2012. According to the results, SMEs' innovation capacity was positively related to technological innovation performance, and SMEs' skills and technology acquisition is a contextual factor that positively influences their innovation performance. In this process, SMEs' innovation capacity is a partial mediator between skills and technology acquisition and SMEs' technological innovation performance. Moreover, the results show that the relationship between government and public policies and SMEs' innovation performance is mediated by SMEs' internal innovation capacity. The results imply that both skills and technology acquisition and government and public policies are important contextual factors can increase SMEs' innovation performance. Based on the results, this study provides implications for policy makers in terms of the policies that provide both direct and support roles in fostering and sustaining innovation, which drives regional economic growth and development.
\end{abstract}

Keywords: technological innovation; small and medium-sized enterprises (SMEs); contextual factors; structural equation modeling (SEM)

\section{Introduction}

The manufacturing industry is the backbone of our economy and has a paramount importance in regional economic and social development. However, the manufacturing industry has been facing a number of issues recently, such as sustainability [1]. In this vein, a growing number of studies have paid particular attention to the role of innovation processes in firms' sustainable development [2]. This is because sustainability has long been recognized as an innovative and potentially transformational force that creates new products and processes that challenge existing practices [2,3]. Moreover, technological innovation through innovation processes can help firms achieve sustainable production, which drives sustainable success and survival in firms. This in turn is the main engine of firms' economic growth and a driver of urban and regional economic growth [4] that fosters regions' global competitiveness.

Most recent research on both sustainable development and innovation mainly studied the context of large firms [2,5]. Thus, a substantial body of research ignores the significant contribution of small and medium-sized enterprises (SMEs) [2] to employment, job creation, and economic growth, as new technologies reduce the significance of economies of scale in innovation activities [6-10]. For instance, according to the OECD [11], SMEs account for over $95 \%$ of firms and $60 \%$ of employment, and represent a large share of new job creation as well as the highest sales and employment growth 
in OECD countries, even after controlling for firm age. Furthermore, SMEs potentially contribute to technological innovation and economic growth $[12,13]$. Namely, SMEs play a pivotal role in promoting and sustaining innovation-based regional economic growth and development.

However, despite their important role, many SMEs face tremendous challenges in their attempts to pursue technological innovation [14-16], including financial constraints, a lack of information, weak inter-firm linkages, and regulatory burdens $[17,18]$. These challenges often prevent SMEs from innovating and reaching long-term sustainable survival. To lessen SMEs' challenges, many governments have implemented policy initiatives to improve their access to external resources such as financing aid, information and knowledge infrastructure, and networking [14]. This support can create a favorable business environment that can help promote and sustain innovation and industrial development [19-21]. SMEs also attempted to compensate for their own deficits by creating new information from external knowledge sources, exploiting knowledge from their external environment, and creating external networks with universities that are likely to improve SMEs' innovative capabilities [14,22]. This is because innovation is currently viewed as an interactive process rather than an economic relationship [5]. Thus, as with external collaborative arrangements, SMEs can alleviate internal resource deficiencies and access sophisticated technology [14]. Despite the important role of external resources, many previous studies left this research gap unfilled. Only a few works focused on clarifying the roles of various factors, particularly the contextual factors crucial for SMEs to survive and achieve their impressive innovation performance [21,23]. In this vein, the field requires studies that approach SMEs' innovation performance from both the internal and external view of the conditions required for sustainability.

In Korea, the role of technological innovation is especially important because the country has experienced remarkable economic growth driven by technological innovation since 1990. The Korean government has been aware of the importance of developing technological advantages through innovation activity since the early 1990s, extending the inter-regional industrial link structure, and shifting the locus of research and development $(R \& D)$ from the government to private firms. This increasing awareness of the role of technological innovation in Korea was also reflected in the explosive growth in patent applications since the 1990s, which soared dramatically from 127,810 to 430,164 from 1992 to 2013. Moreover, the structural characteristics of Korean industries are a main reason for the significant impact of technological innovation. The Korean economy relies heavily on the manufacturing sector in its total gross output. According to data published by the Bank of Korea, the manufacturing sector accounted for half of Korea's total gross output in 2010, exceeding the OECD average of $26 \%$. Moreover, the manufacturing sector's contribution to total gross output has consistently increased between 2000 and 2010. In light of these tendencies and of some of the current work in the field, policymakers are consistently interested in how to foster technological innovation and enhance its economic impact on manufacturing SMEs in Korea.

A substantial body of the literature has focused on the drivers and outcomes of innovativeness at the individual firm level. However, one of the main streams of these innovation studies fails to consider the contextual factors that potentially act as key drivers of firms' innovativeness, while another stream does not consider the mediating effect of firms' internal innovation activities on the relationships between the drivers of innovation and innovation performance in the context of SMEs. Therefore, this study sets out to examine the relationship between firms' innovation performance and its drivers in terms of firms' internal and external factors, and to investigate the function of firms' internal innovation activities as a mediator in the link between the drivers of innovation and innovation performance in the context of Korean SMEs. Based on a review of the literature, this study presents a hypothesized research model and tests the research hypotheses using a structural equation model with firm-level data from the Korean Innovation Survey conducted by the Science and Technology Policy Institute in 2012. 


\section{Literature Review and Research Hypotheses}

Innovation studies sought to explain why certain firms innovate more than others do by identifying a number of determinants. However, how innovation occurs and the factors that foster innovation capacity and drive successful innovation performance still remains a challenging area. Although there is a wide range of issues related to innovation and its explanatory factors, many studies failed to integrate all relevant constructs comprehensively. An integrated framework is thus needed to provide a comprehensive and coherent overview of the innovation field's characteristics. This is due, in part, to the expectation that SMEs can obtain mutual benefits that could not be achieved independently [14] by interacting with various forms of organizational arrangements and by networking with external organizations including other firms, universities, the public, and governments. Such a network perspective provides a fuller picture of SMEs' innovation activities [24]. Thus, we proposed a research model of innovation based on Becheikh et al. [25], who designed the comprehensive framework based on a thorough review and analysis of a wide range of innovation studies.

However, although the comprehensive approach has some appeal, a substantial body of literature, including Becheikh et al. [25], has a major drawback. Despite the important role of the absorptive capacity of innovator firms [26], they overlooked the absorptive capacity argument in innovation studies and thus failed to account for its role in firms' innovation. As Cohen and Levinthal [26] and Oerlemans et al. [27] state, the absorptive capacity of innovator firms refers to "the ability to learn, assimilate, and use knowledge developed elsewhere through a process that involved substantial investments." In other words, innovation capacity or capabilities imply "the tangible and intangible assets firms use to develop and implement their strategies" [28] or "the ability of the organization to recognize the technical and economic value of new knowledge and routines, assimilate, and apply them to new product development projects" [29].

Individual firms, particularly SMEs, are hardly capable of innovating independently [30]; a firm's capacity for innovation is necessarily improved by an extended knowledge base, cost reduction, and risk sharing offered through extensive links, networks with other organizations, and knowledge and technology acquisition [30,31]. That is, knowledge is at the base of the construction of firms' capabilities [32]. Furthermore, innovations are products of a firm's combinative capabilities that can generate new applications from existing knowledge [33]. Piecing this together, Figure 1 illustrates our research model by showing the link between innovation capacity and performance and the effects of both internal and external factors on innovation capacity and eventual innovation performance.

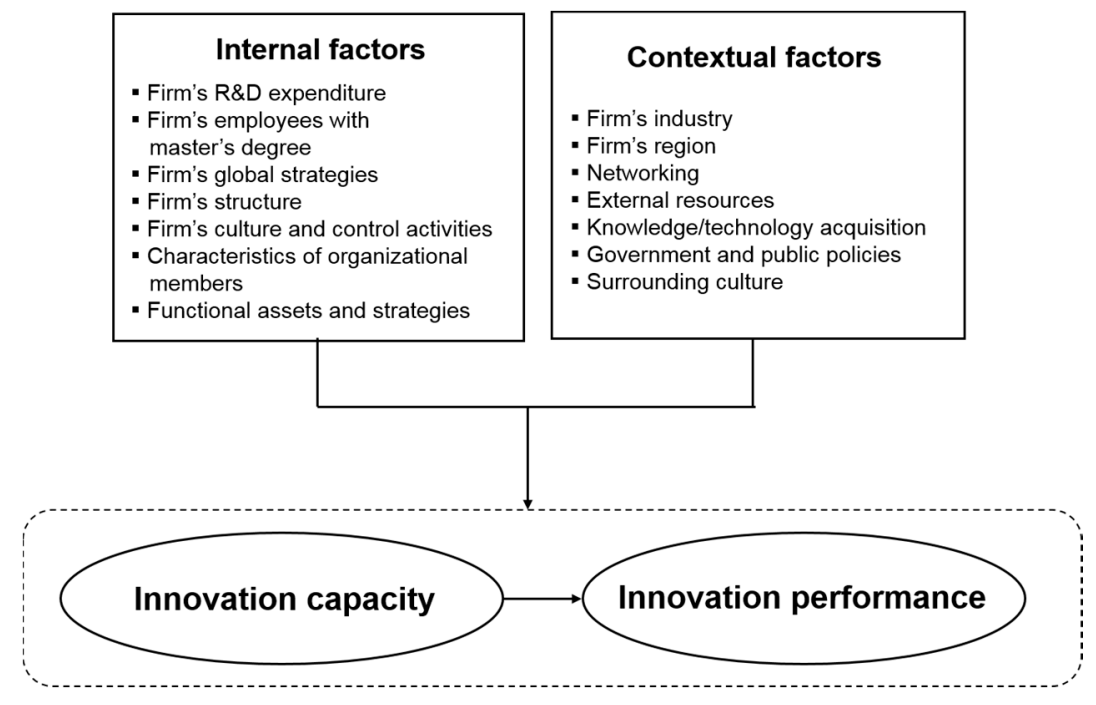

Figure 1. Comprehensive research model of innovation. 
As previously mentioned, resources and capacities can help to drive innovation. In light of how innovation depends on external knowledge, absorptive capacity plays a particularly important role in increasing a firm's ability to create new knowledge that fosters the emergence of innovation [26]. The resource-based view also emphasizes that resources and capabilities are important factors for firms to develop competitive advantages that eventually drive innovation $[5,28,33,34]$. Then, what factors can help enhance the firm's innovation capacity? Among the internal firm-level factors of size, sales, exports, stock of human capital inputs, amount of R\&D investment, and R\&D activities [13,35-41], $R \& D$ has received the most attention from previous studies [5,42]. In other words, many researchers regarded $R \& D$ as the most important driver of innovation [43,44], particularly in the context of SMEs [45]. According to Cohen and Levinthal [42], R\&D creates new information and enhances the firm's ability to facilitate the assimilation of new technology and exploit existing information, what we call a firm's innovation capacity. Ray et al. [28] also stated that new resources enable a firm to develop new sources of competitive advantage. In this light, R\&D expenditure and percentage of higher educated workforce are widely considered as basic measures of innovation-related resources [5,46,47]. These measures imply the degree of knowledge intensity and of the absorptive capacity of the firm [5]. Prior research also found evidence that R\&D investment is one of the most important mechanisms that determines the overall level of innovation in an industry [48]. Therefore, we suggest that:

Hypothesis 1 (H1). SMEs' innovation capacity related to RED activities is positively associated with their innovation performance.

However, simply examining the relationship between a firm's internal resources and its innovation performance can lead to misleading conclusions [28]. The environmental view complements the resource-based view by focusing on the important role of structural forces in the firm's operating environment and socioeconomic influences [5], and emphasizing communication with external sources of expertise and collaborative links between the firm and its environment through its participation in inter-organizational relationships and networks [31]. Similarly, over the last two decades, the literature on innovation has identified a tremendous systematic and fundamental change in how firms drive innovation performance. New innovation models showed that many innovative firms are changing how they search for new ideas, adopting open search strategies that involve the use of a wide range of external actors and sources to help them achieve and sustain innovation. In particular, new methods that integrate contextual factors from outside firms play a pivotal role in driving innovation in SMEs because they generally have difficulty innovating due to deficits in resources, financing aids, networking, and knowledge assets $[8,49]$. Therefore, innovative firms that cannot rely on their own internal capabilities and resources, particularly SMEs, may seek to establish formal or informal links and networks with external organizations to fill their innovation capacity with external organizations [24].

The description of innovation above shows that for firms, particularly SMEs, innovation performance is influenced by socially specified, extra-organizational factors such as extensive external links, technology networks, and external agency (e.g., universities, public agencies) [30]. In the era of "open innovation" and the "knowledge-based economy," external factors such as external ideas and knowledge, resources, and networks have an increasingly significant influence on SMEs' innovation [50,51]. Some studies noted that the inter-organizational links of networks with other institutions play an important role in the creation and diffusion of technological knowledge, allowing for the patenting of activities through crucial external nodes such as universities, research institutions, and other firms [52,53]. For example, Freel [14] argues that university links enable SMEs to improve their innovative capacity or capabilities by gaining access to sophisticated technology and technical expertise. Therefore, networking can act as a complementary factor that allows for the merging and integration of diverse skills, technologies, and competencies [54], and providing the stimulus and capacity to innovate [55]. SMEs can gain particular advantages from networks because they can help offset the size-related advantages of larger firms [56]. Many studies also found convincing evidence 
that network cooperation or the use of a wide range of external knowledge and sources is a way to supplement and complement internal resources that could contribute to firms' successful innovation output $[14,22,57,58]$. This prompted the following hypotheses:

Hypothesis 2a (H2a). SMEs' networking, that is, inter-firm cooperation and collaboration with other institutions and the acquisition of external knowledge, is positively associated with their internal innovation capacity.

Hypothesis 2b (H2b). SMEs' networking, that is, inter-firm cooperation and collaboration with other institutions and the acquisition of external knowledge, is positively associated with their innovation performance through their internal innovation capacity.

In addition, technology acquisition from external institutions in more advanced countries is obviously another important contextual factor for firms from industrializing countries attempting to catch up technologically [59,60]. According to Knight, technology acquisition refers to "efforts by management to acquire technologies that will augment the firm's ability to compete in international markets, via the creation of superior products and/or processes" [61] (p. 161). Firms without the appropriate knowledge or technology within the firm can search for external technology by cooperating with other firms or by creating partnerships with public and private institutions [62]. Introducing new knowledge, technology, and skills from external partners provides unique learning opportunities [63]. Moreover, acquiring technology is likely to support product development and adaptation and encourage the firm to enter complex foreign markets [61]. In particular, for SMEs with a limited range of technology, acquiring external technology from universities, research institutions, governments, and firms can compensate for a limited capacity to absorb new technology. This more active and greater use of technology assets provides an opportunity for SMEs to develop their innovation capabilities [64]. Tidd and Trewhella [65] also highlight the learning aspect of external technology acquisition and its important role in innovation.

In addition to acquiring technology, a quality workforce is an important foundation for innovation activity. The on-the-job training (OJT) method fosters a qualified workforce that drives innovation. The most common forms of OJT in SMEs are job instruction training and apprenticeships. In general, SMEs significantly use OJT due to its low cost and the preponderance of the use of ad hoc training [66]. According to Beaver and Hutchings [66], SMEs with OJT have more opportunities to benefit from maximizing knowledge transfer. That is, OJT is an important channel for employees to upgrade their skills and remain competitive in the labor market by receiving practical advice and personal assistance, and for firms to adopt technology and innovation [67]. Many studies-mostly in developed countries-show a positive relationship between OJT and increases in employees' wages because it equips them with relevant labor market skills, ultimately driving firms' productivity and innovation [67]. Therefore, we formulated the following hypotheses:

Hypothesis 3a (H3a). The acquisition of skills and technology positively influences SMEs' internal innovation capacity.

Hypothesis $\mathbf{3 b} \mathbf{b} \mathbf{H} \mathbf{3 b})$. The acquisition of skills and technology positively influences SMEs' innovation performance through their internal innovation capacity.

Prior studies have noted that SMEs previously suffered from fiscal and regulatory constraints due to their limited access to finance and the lack of an effective institutional structure. In this vein, many studies highlighted the role of government policy because the government will employ the requisite technical knowledge and technology or give firms access to its considerable resource networks [14]. The government may play an important role in managing a network. Moreover, creating a favorable business environment is also a prerequisite for SMEs to undertake technological change [19,68-70]. According to Patanakul and Pinto [21], government and public policies can foster favorable cultures that create an entrepreneurial environment and promote firms' willingness to 
change by providing fiscal incentives, tax credits, and easily accessible information, thereby promoting innovation. In addition, government support programs play a key role in providing immediate technical and managerial training programs needed to drive SMEs' innovation [8]. In this respect, there is much evidence suggesting that governments could encourage SMEs' innovation capacity, which eventually promotes SMEs' innovation performance and scientific research by providing seed grants and start-up money through direct support payments or non-monetary grants [21]. Thus, innovative SMEs are more likely to have had contact and networks with public sector support agencies and government departments [14]. Based on this analysis, we hypothesized that:

Hypothesis 4a (H4a). Government and public policies to provide fiscal incentives and information are positively associated with SMEs' internal innovation capacity.

Hypothesis $\mathbf{4 b} \mathbf{( H 4 b )}$. Government and public policies to provide fiscal incentives and information are positively associated with SMEs' innovation performance through their internal innovation capacity.

Based on the discussion above, we propose the hypothesized causal relationships illustrated in the research model in Figure 2. The causal relationships suggest that increasing SMEs' innovation capacity increases their capacity to use their internal and external resources to increase product or process innovation.

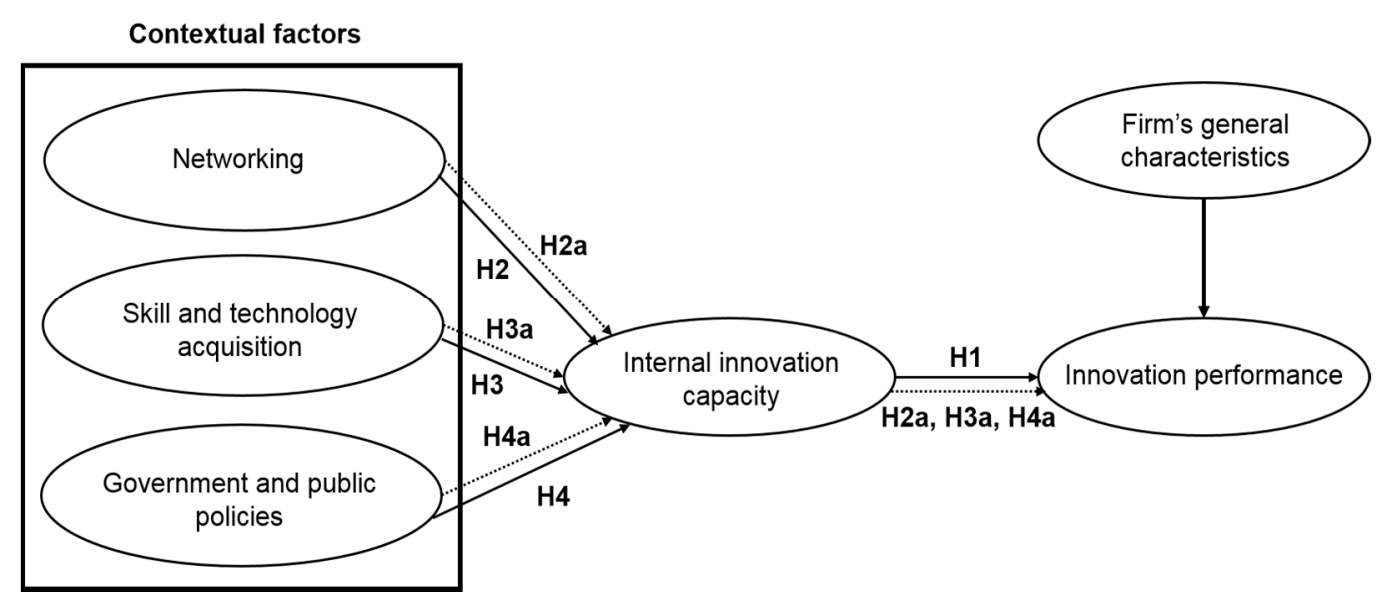

Figure 2. Hypothesized research model.

\section{Methodology and Measurement}

\subsection{Data and Sample}

We analyze manufacturing SMEs based on firm-level data from the Korean Innovation Survey conducted by the Science and Technology Policy Institute in 2012. The survey was designed to collect information about the innovation performance of individual manufacturing firms in the three-year period from 2009 to 2011. The data provide relevant information about firms' general characteristics, innovation activities, and innovation performance. The Korean Innovation Survey followed the innovation survey design principles of the Oslo Manual [71] and collected specific information about manufacturing SMEs' technological innovation outputs, subdividing technological innovation into product and process innovation. The original data in the Korean Innovation Survey for the manufacturing industry was collected from 4086 Korean manufacturing firms. After excluding large enterprises, firms located outside the capital, missing values, and outliers, we use the remaining sample of 212 manufacturing SMEs from the capital region for the analysis. We focus on the capital region because most industries are located in urban areas, and particularly in the northwest parts of Korea that form the capital region. 


\subsection{The Measurement of the Constructs}

This study uses structural equation modeling to investigate the effect of contextual factors on manufacturing SMEs' innovation performance through firms' internal innovation activities. The construct items were mainly adapted from previous studies and modified for use in an innovation context. Table 1 provides a brief explanation of the latent variables. We measured all constructs with multiple items. First, innovation performance as a dependent variable measured with two items operationalized according to the number of patent applications for product and process innovation, respectively. Innovation is most widely defined as "a process of commercialization of a newly developed or adopted product or practice." [24,72]. Despite the wide range of types of innovation, much of the literature on innovation concentrated on technological innovation such as new products and new production processes [24], and the most innovations focused on product and process innovations since the 1950s [72]. This is because innovation is, by definition, the creation of something qualitatively different, so that new products and technologies must be evaluated to detect whether they can be translated into new product/process features [27]. Furthermore, innovation in products and processes especially are considered as a key driver of the economic performance and growth of SMEs $[14,16,47]$. This is due to the expectation that SMEs' product and process improvements or innovations have greater influence on growth and profit performance than other types of innovation. Therefore, our study mainly considers product and process innovation.

Table 1. Explanation of latent variables.

\begin{tabular}{|c|c|c|}
\hline Latent Variables & Indicators & Cronbach's ff \\
\hline \multirow{2}{*}{$\begin{array}{l}\text { Innovation } \\
\text { performance }\end{array}$} & $\begin{array}{l}\text { Average number of patent application related to product innovation } \\
\text { between } 2009 \text { and } 2011\end{array}$ & \multirow{2}{*}{0.302} \\
\hline & $\begin{array}{l}\text { Average number of patent application related to process innovation } \\
\text { between } 2009 \text { and } 2011\end{array}$ & \\
\hline \multirow{3}{*}{$\begin{array}{l}\text { Firm's internal } \\
\text { innovation capacity }\end{array}$} & $\begin{array}{l}\text { Dummy variable for firm's internal research and development (R\&D) } \\
\text { activity }(=1 \text {, performed) }\end{array}$ & \multirow{3}{*}{0.529} \\
\hline & Average number of R\&D employees between 2009 and 2011 & \\
\hline & $\begin{array}{l}\text { Average number of employees with a master's degree between } \\
2009 \text { and } 2011\end{array}$ & \\
\hline \multirow{4}{*}{ Networking } & $\begin{array}{l}\text { Dummy variable for the firm's external knowledge acquisition } \\
(=1 \text {, performed })\end{array}$ & \multirow{4}{*}{0.661} \\
\hline & Dummy variable for joint firm R\&D activity (=1, performed) & \\
\hline & $\begin{array}{l}\text { Dummy variable for firm's R\&D activity with external organizations } \\
(=1, \text { performed })\end{array}$ & \\
\hline & $\begin{array}{l}\text { Dummy variable for collaboration with other organizations on } \\
\text { innovation activity }(=1 \text {, performed) }\end{array}$ & \\
\hline \multirow{2}{*}{$\begin{array}{l}\text { Skill and technology } \\
\text { acquisition }\end{array}$} & Dummy variable for firm's on-the-job training (=1, performed) & \multirow[b]{2}{*}{0.707} \\
\hline & $\begin{array}{l}\text { Dummy variable for the firm's machine, equipment, and software } \\
\text { acquisition (=1, acquired) }\end{array}$ & \\
\hline \multirow{3}{*}{$\begin{array}{l}\text { Government and } \\
\text { public policies }\end{array}$} & $\begin{array}{l}\text { Dummy variable for firm government funding to support innovation } \\
\text { activity (=1, funded) }\end{array}$ & \multirow{3}{*}{0.567} \\
\hline & $\begin{array}{l}\text { Dummy variable for the use of information about innovation activity } \\
\text { provided by governmental and public institutions }(=1 \text {, used) }\end{array}$ & \\
\hline & $\begin{array}{l}\text { Dummy variable for the use of governmental financial aid or tax } \\
\text { reduction }(=1 \text {, used })\end{array}$ & \\
\hline \multirow{3}{*}{$\begin{array}{l}\text { Firm's general } \\
\text { characteristics }\end{array}$} & Average number of employees between 2009 and 2011 & \multirow{3}{*}{0.793} \\
\hline & Average sales from 2009 to 2011 (billion Korean won) & \\
\hline & Average volume of exports from 2009 to 2011 (billion Korean won) & \\
\hline
\end{tabular}


Following the Oslo Manual, we defined product innovation as the introduction of "a product whose technological characteristics or intended uses differ significantly from those of previously produced products" or "an existing product whose performance has been significantly enhanced or upgraded" [71] (p. 32). We defined process innovation as "the adoption of technologically new or significantly improved production methods" [71] (p. 32) on the market. We used the number of patent applications to measure the innovation performance of manufacturing SMEs. Though this measure has some limitations and has been challenged, patented inventions still provide a fairly reliable measure of firm-level innovation performance [8,73]. Some studies warned that the number of patent is not the equivalent of a direct measure of innovative output because not all new innovations are patented [74,75] and patents do not measure the economic value of new technology creation [73].

However, many studies provided evidence that the patent measure can substitute for the number of innovations. According to Acs and Audretsch [76], patents provide a fairly reliable measure of innovative at the industry level. Acs et al. [77] also found evidence that patents and innovations behave similarly at the state level. In addition, Acs et al. [73] assessed the extent to which patents may be used as a reliable proxy of innovation activity, observing that the correlation between the patent and innovation count at the state level is reasonably high. In this way, a substantial body of the empirical findings supports the use of patent counts in this study of innovation. Furthermore, the Korean Innovation Survey provides only the patents count data, not a direct measure of innovation. We thus used patent data to measure SMEs' innovation.

We assessed firms' ability to achieve innovation performance independently based on their internal innovation capacity, which we quantified using average number of employees with a master's degree, average number of R\&D employees, and a dummy variable for firms' internal R\&D activity $(1=$ performed). To represent firms' internal innovation capacity, we selected specific items from the questionnaires, including networking, skill and technology acquisition, and government and public policies as contextual factors. We measured networking with four items used in several previous studies [50-53,78] to focus on the mutual benefits in overcoming SMEs' disadvantages relative to larger counterparts through the establishment of co-operative R\&D systems and external networks involving other firms, such as universities and private sector research institutes. We measured networking with four items that were operationally defined as follows: a dummy variable for joint firm R\&D activity ( 1 = performed); a dummy variable for firms' R\&D activity with external organizations $(1=$ performed); a dummy variable for collaboration with other organizations on innovation activity $(1=$ performed), and; a dummy variable for the firm's external knowledge acquisition $(1=$ acquired $)$.

In addition, based on prior studies $[59,60,62,64]$, we assessed skill and technology acquisition as a contextual factor with a dummy variable for the firm's machine, equipment, and software acquisition ( $1=$ acquired); and a dummy variable for firms' on-the-job training ( 1 = performed). Another contextual factor affecting firms' internal innovation capacity is government and public policies. We measured the latter with three items from previous studies $[8,19,21,68-70]$, which we operationally defined as a dummy variable for government funding to support innovation activity $(1=$ funded $)$, a dummy variable for the use of government- and public institution-provided information about innovation activity $(1=$ used $)$, and a dummy variable for the use of government financial aid or tax reduction $(1=$ used). Moreover, we included control variables for other factors influencing SMEs' innovation performance, including firm size, sales, and exports. Firms with a high volume of sales and exports are more likely to invest more in $R \& D$ and to gain a competitive advantage. The resource-based view emphasizes the important role of resources and capabilities in the development of competitive advantage [5,34]. In particular, a firm's size, which is generally measured by the number of employees, is one of the main factors affecting innovation performance [79]. Many Schumpeterian studies also tested this hypothesis by examining the relationships between firm size and innovation performance at the firm level [80]. Thus, these general characteristics affect both product and process innovation [8,81-83]. For empirical analysis, we operationalized firm size as the average number of employees between 2009 and 2011, sales as the average sales from 2009 to 2011, 
and exports as the average volume of exports from 2009 to 2011. We found that the average number of employees, sales, and volume of exports between 2009 and 2011 obtained from the sample is about 70 employees, about 205.511 billion Korean won, and about 69.968 billion Korean won, respectively. Table 2 reports the descriptive statistics for the variables.

Table 2. Descriptive statistics of the sample $(n=212)$.

\begin{tabular}{|c|c|c|c|c|}
\hline Variables & Mean & $\begin{array}{l}\text { Standard } \\
\text { Deviation }\end{array}$ & Min. & Max. \\
\hline \multicolumn{5}{|l|}{ Innovation performance } \\
\hline $\begin{array}{l}\text { Average number of patent application related to product innovation between } \\
2009 \text { and } 2011\end{array}$ & 5.179 & 8.791 & 0 & 70 \\
\hline $\begin{array}{l}\text { Average number of patent application related to process innovation between } \\
2009 \text { and } 2011\end{array}$ & 0.231 & 1.532 & 0 & 18 \\
\hline \multicolumn{5}{|l|}{ Firm's internal innovation capacity } \\
\hline Average number of employees with a master's degree between 2009 and 2011 & 4.688 & 12.418 & 0 & 100 \\
\hline Average number of R\&D employees between 2009 and 2011 & 10.250 & 1.083 & 0 & 110 \\
\hline Dummy variable for firm's internal R\&D activity $(=1$, performed) & 0.970 & 0.179 & 0 & 1 \\
\hline \multicolumn{5}{|l|}{ Networking } \\
\hline Dummy variable for joint firm $R \& D$ activity $(=1$, performed) & 0.360 & 0.481 & 0 & 1 \\
\hline $\begin{array}{l}\text { Dummy variable for firm's } R \& D \text { activity with external organizations } \\
(=1 \text {, performed })\end{array}$ & 0.190 & 0.392 & 0 & 1 \\
\hline $\begin{array}{l}\text { Dummy variable for collaboration with other organizations on innovation } \\
\text { activity (=1, performed) }\end{array}$ & 0.420 & 0.494 & 0 & 1 \\
\hline Dummy variable for the firm's external knowledge acquisition (=1, performed) & 0.120 & 0.323 & 0 & 1 \\
\hline \multicolumn{5}{|l|}{ Skill and technology acquisition } \\
\hline Dummy variable for firm's on-the-job training $(=1$, performed) & 0.56 & 0.034 & 0 & 1 \\
\hline $\begin{array}{l}\text { Dummy variable for the firm's machine, equipment, and software acquisition } \\
(=1 \text {, acquired) }\end{array}$ & 0.570 & 0.496 & 0 & 1 \\
\hline \multicolumn{5}{|l|}{ Government and public policies } \\
\hline $\begin{array}{l}\text { Dummy variable for firm government funding to support innovation activity } \\
\text { (=1, funded) }\end{array}$ & 0.100 & 0.306 & 0 & 1 \\
\hline $\begin{array}{l}\text { Dummy variable for the use of information about innovation activity provided } \\
\text { by governmental and public institutions (=1, used) }\end{array}$ & 0.300 & 0.458 & 0 & 1 \\
\hline $\begin{array}{l}\text { Dummy variable for the use of governmental financial aid or tax reduction } \\
(=1, \text { used })\end{array}$ & 0.448 & 0.498 & 0 & 1 \\
\hline \multicolumn{5}{|l|}{ Control variables } \\
\hline Average number of employees between 2009 and 2011 & 70.289 & 103.284 & 9 & 800 \\
\hline Average sales from 2009 to 2011 (billion Korean won) & 205.511 & 251.846 & 10 & 1000 \\
\hline Average volume of exports from 2009 to 2011 (billion Korean won) & 69.968 & 158.588 & 0 & 1000 \\
\hline
\end{tabular}

\section{Empirical Results}

We tested the hypotheses using the results from a decomposition of effects, by which the total effects of an explanatory variable on a dependent variable are disaggregated into its direct and indirect effects. Structural equation modeling (SEM) is a powerful multivariate technique that uses a conceptual model, a path diagram, and a system of linked regression-style equations to capture the complex and dynamic relationships in a web of observed and unobserved variables. The method helps to explain how or why an independent variable influences an outcome (dependent variable) through an intermediate variable (mediator). We therefore used this approach to test the relationships proposed in the research model. We used the AMOS 20.0 software (IBM SPSS, Chicago, IL, USA) package to obtain the SEM results for the confirmatory analysis of the research framework and hypothesized relationships between innovation and the internal/external factors in our research model. Table 3 provides the test results for the effects of contextual factors on SMEs' technological innovation outputs through their 
internal innovation capacity, with the control variables (firm's size, sales, and exports). A significant indirect effect means that the mediator causes a significant quantity of the independent variable's total effect on the dependent variable. Figure 3 presents the individual structural path estimates, including the paths' direct and indirect effects. The SEM fit results in Table 3 indicate a statistically significant chi-squared value $\left(\chi^{2}(113)=401.6, p=0.00\right)$. The other goodness-of-fit values from the results were as follows: Normed Fit Index $(\mathrm{NFI})=0.628$, Root Mean Square Error of Approximation $($ RMSEA) $=0.110$, and Akaike Information Criterion $(\mathrm{AIC})=515.622$. The results indicate an acceptable fit to the model .

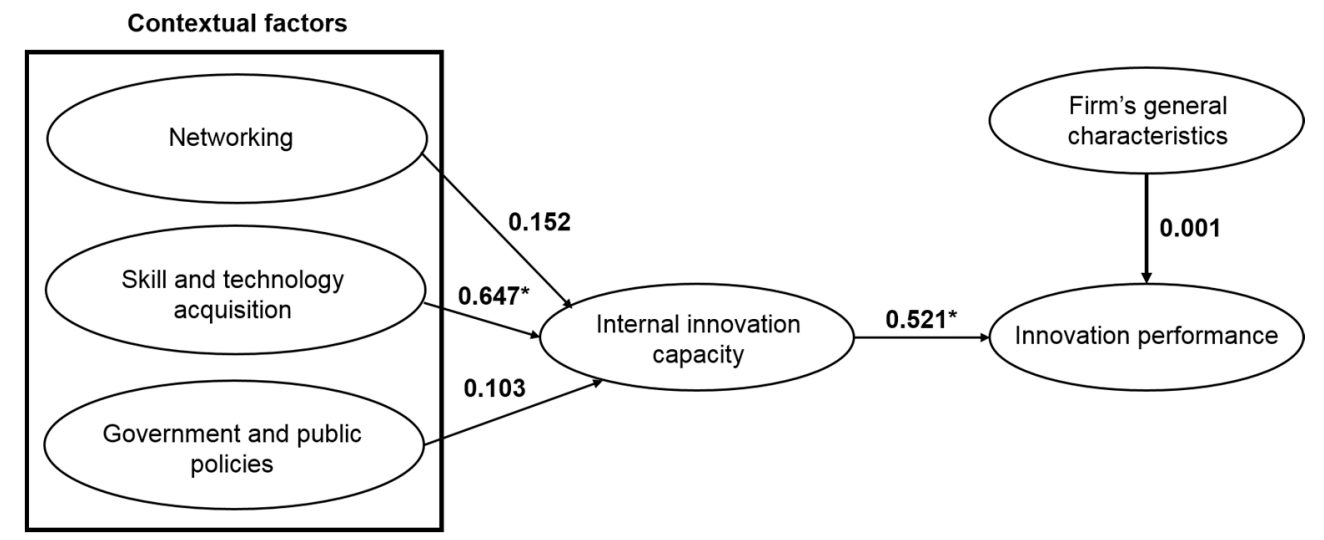

Figure 3. Results for the structural model. ${ }^{*} p<0.10,{ }^{* *} p<0.05,{ }^{* * *} p<0.01$.

Table 3. The test results of causal paths by bootstrapping.

\begin{tabular}{lc}
\hline \multicolumn{1}{c}{ Paths and Corresponding Hypotheses } & Standardized Coefficient \\
\hline H1: Internal innovation capacity $\rightarrow$ innovation performance & $0.521^{*}$ \\
H2a: Networking $\rightarrow$ internal innovation capacity & 0.152 \\
H2b: Networking $\rightarrow$ internal innovation capacity $\rightarrow$ innovation performance & 0.079 \\
H3a: Skill and technology acquisition $\rightarrow$ internal innovation capacity & $0.647^{*}$ \\
H3b: Skill and technology acquisition $\rightarrow$ internal innovation capacity $\rightarrow$ innovation performance & $0.337^{* *}$ \\
H4a: Government and public policies $\rightarrow$ internal innovation capacity & 0.103 \\
H4b: Government and public policies $\rightarrow$ internal innovation capacity $\rightarrow$ innovation performance & $0.054^{*}$ \\
\hline \multicolumn{2}{c}{$*<<0.10^{* *} p<0.05^{* * *} p<0.01}$.
\end{tabular}

We can test the hypotheses by interpreting the structural path coefficients. The results in Table 3 show that SMEs' innovation capacity had a positive effect on technological innovation performance $(\hat{\beta}=0.521)$, supporting $H 1$, and is consistent with results in prior studies $[5,26,28,33,34,45,48]$. Namely, SMEs making a large investment in their innovation capacity would have better innovation performance. For the effect of contextual factors of networking, acquisition of skill and technology, and government and public policies on SMEs' innovation performance in $\mathrm{H} 2 \mathrm{a}$, networking positively influenced innovation capacity $(\hat{\beta}=0.152)$, as expected $[14,31,50-58]$. However, networking for SMEs did not represent a statistically significant effect on innovation capacity for SMEs. Thus, SMEs should focus on building their innovation capacity rather than their networks to enhance their product and process innovation.

In addition to networking, as previous studies supported [59-62,66,67], skill and technology acquisition was positively associated with SMEs' innovation capacity $(\hat{\beta}=0.647)$, which confirmed H3a. Therefore, as Knight [61] supported, acquiring skills and technology influenced SMEs' innovation capacity directly. However, the link between government and public policies and innovation capacity for SMEs $(\hat{\beta}=0.103)$ was not statistically insignificant. We could not conclude that this statistically insignificant relationship supports $\mathrm{H} 4$. As mentioned above, the results indicated that a contextual variable such as skill and technology acquisition was a crucial factor fostering SMEs' internal innovation capacity, as expected. 
In addition to the direct effects of the hypothesized paths, we estimated the indirect effects to identify the function of SMEs' innovation capacity in the relationships between the contextual factors and the innovation performance. For $\mathrm{H} 2 \mathrm{~b}$, the path results showed that SMEs' innovation performance was in part positively influenced by networking activities through SMEs' innovation capacity $(\hat{\beta}=0.079)$. However, this link was not statistically significant. The results in Table 3 show a partial mediation of SMEs' innovation capacity in the significant relationship between their innovation performance and the acquisition of skills and technology $(\hat{\beta}=0.337)$, which supported H3b and concurs with previous studies $[64,65,67]$. The results of both H3a and H3b mean that the acquisition of skills and technology influenced SMEs' innovation capacity directly, and had an indirect positive effect through SMEs' innovation capacity as Tidd and Trewhella [65] and Knight [61] reported. The path coefficients also show the positive influence of government and public policies in the relationship between SMEs' innovation performance and innovation capacity; that is, SMEs' innovation performance was positively influenced by government and public policies through their internal innovation capacity $(\hat{\beta}=0.054)$. This statistically significant link supported $\mathrm{H} 4 \mathrm{~b}$ and is in line with previous studies $[8,14,21]$. Thus, the government and public institutes can encourage innovative SMEs through tax benefits, loans, grants, and other non-fiscal support by enhancing SMEs' internal innovation capacity.

Some previous studies reported similar findings; therefore, $\mathrm{H} 1, \mathrm{H} 3 \mathrm{a}, \mathrm{H} 3 \mathrm{~b}$, and $\mathrm{H} 4 \mathrm{~b}$ were supported. That is to say, SMEs' internal innovation capacity has a role in the effects of contextual factors on innovation performance as previous studies reported $[5,26,28,33,34]$. We also estimated the effects of the control variables on SMEs' innovation performance, which verified the proposed relationships, regardless of SMEs' general characteristics.

\section{Conclusions}

This study examined the relationships between certain contextual drivers of innovation performance and the mediation effects of SMEs' innovation capacity in manufacturing SMEs located in metropolitan areas of Korea. We suggest that contextual factors such as skills and technology acquisition and government and public policies are key factors fostering SMEs' internal innovation capacity and innovativeness based on our results. Based on explanatory investigations of the hypothesized relationships suggested by prior studies, our findings empirically verified that both contextual and internal factors play a central role in creating and sustaining SMEs' innovation performance through their innovative capacity.

According to the empirical results of our study, SMEs' innovation capacity was positively related to technological innovation performance. The results also show that SMEs' skills and technology acquisition as a contextual factor positively influenced their innovation performance. In this process, SMEs' innovation capacity has a critical role as a mediator between skills and technology acquisition and SMEs' technological innovation performance. Namely, if SMEs increase their innovation capacity by investing in resources, SMEs can expect to have better innovation performance. Moreover, the results show that the relationship between government and public policies and SMEs' innovation performance was mediated by SMEs' internal innovative capacity. However, networking did not significantly influence either SMEs' internal innovation capacity or their innovation performance. The results imply that both skills and technology acquisition and government and public policies are important contextual factors influencing the increase in SMEs' innovation performance.

Over the past few decades, the drivers of manufacturing SMEs' technological innovation have become important issues in Korea. Despite the high interest, there is little research on the contextual factors that can affect SMEs' internal innovation capacity and innovation performance, and there is no specific guideline and integrated design scheme for Korea. To overcome these shortcomings, this study suggested a comprehensive model of technological innovation performance for SMEs and empirically investigated the model. This study also adds to the knowledge in this field by considering more relevant variables based on the findings in innovation studies targeting SMEs. Moreover, our findings imply that contextual factors such as skills and knowledge acquisition, networking, and government 
and public policies are important for SMEs' innovation, as well as their internal factors, which can fill the research gap in previous studies. Thus, to enhance SMEs' innovation performance, it is essential to establish integrated strategies.

The study has several limitations. First, we used a limited number of predictors and control variables due to limited data access. Therefore, future research should consider other potentially significant factors that may be associated with SMEs' innovation performance. Second, the detailed process of how contextual factors affect SMEs' innovation performance via their internal innovation capacity was not fully examined. We could only conceptualize that contextual factors can function as essential elements in SMEs' innovation. Third, we looked only at firm-level data from one point in time. To lessen these shortcomings, future research can conduct examine different levels (i.e., firms, regions) and investigate several observations of the same subjects over time. We could then discuss the differences in the research results in different periods.

Author Contributions: Ye Seul Choi designed the research and drafted the manuscript. Up Lim guided this work and provided extensive revisions during the study. Both authors wrote, read, and approved the final manuscript.

Conflicts of Interest: The authors declare no conflict of interest.

\section{References}

1. Herrmann, C.; Schmidt, C.; Kurle, D.; Blume, S.; Thiede, S. Sustainability in manufacturing and factories of the future. Int. J. Precis. Eng. Manuf.-Green Technol. 2014, 1, 283-292. [CrossRef]

2. Bos-Brouwers, H.E.J. Corporate sustainability and innovation in SMEs: Evidence of themes and activities in practice. Bus. Strat. Environ. 2010, 19, 417-435. [CrossRef]

3. Blum-Kusterer, M.; Hussain, S.S. Innovation and corporate sustainability: An investigation into the process of change in the pharmaceuticals industry. Bus. Strat. Environ. 2001, 10, 300. [CrossRef]

4. Acs, Z.J. Innovation and the Growth of Cities; Edward Elgar: Cheltenham, UK, 2002; pp. 24-43.

5. Hadjimanolis, A. An investigation of innovation antecedents in small firms in the context of a small developing country. $R$ D Manag. 2000, 30, 235-246. [CrossRef]

6. Acs, Z.J.; Audretsch, D.B. Innovation and Small Firms; MIT Press: Cambridge, MA, USA, 1990; pp. 50-59.

7. Liesch, P.W.; Knight, G.A. Information internalization and hurdle rates in small and medium enterprise internationalization. J. Int. Bus. Stud. 1999, 30, 383-394. [CrossRef]

8. Doh, S.; Kim, B. Government support for SME innovations in the regional industries: The case of government financial support program in South Korea. Res. Policy 2014, 43, 1557-1569. [CrossRef]

9. Bloch, H.; Bhattacharya, M. Promotion of innovation and job growth in small and medium-sized enterprises in Australia: Evidence and policy issues. Aust. Econ. Rev. 2016, 49, 192-199. [CrossRef]

10. Sung, C.Y.; Kim, K.C.; In, S. Small and medium-sized enterprises policy in Korea from the 1960s to the 2000s and beyond. Small Enterp. Res. 2017, 3, 262-275. [CrossRef]

11. The Organisation for Economic Co-operation and Development. Small and Medium-Sized Enterprises: Local Strength, Global Reach; OECD Publishing: Paris, France, 2000.

12. Ettlie, J.E.; Rubenstein, A.H. Firm size and product innovation. J. Prod. Innov. Manag. 1987, 4, 89-108. [CrossRef]

13. Acs, Z.J.; Audretsch, D.B. Innovation in large and small firms: An empirical analysis. Am. Econ. Rev. 1988, 78, 678-690. [CrossRef]

14. Freel, M. External linkages and product innovation in small manufacturing firms. Entrep. Reg. Dev. 2000, 12, 245-266. [CrossRef]

15. Gnyawali, D.R.; Park, B.J.R. Co-opetition and technological innovation in small and medium-sized enterprises: A multilevel conceptual model. J. Small Bus. Manag. 2009, 47, 308-330. [CrossRef]

16. Berends, H.; Jelinek, M.; Reymen, I.; Stultiëns, R. Product innovation processes in small firms: Combining entrepreneurial effectuation and managerial causation. J. Prod. Innov. Manag. 2014, 31, 616-635. [CrossRef]

17. Van de Vrande, V.; De Jong, J.P.; Vanhaverbeke, W.; De Rochemont, M. Open innovation in SMEs: Trends, motives and management challenges. Technovation 2009, 29, 423-437. [CrossRef] 
18. Olmos-Peñuela, J.; García-Granero, A.; Castro-Martínez, E.; D’Este, P. Strengthening SMEs' innovation culture through collaborations with public research organizations. Do all firms benefit equally? Eur. Plan. Stud. 2017, 25, 1-20. [CrossRef]

19. Nelson, R.R.; Rosenberg, N. National Innovation Systems: A Comparative Analysis; Oxford University Press: New York, NY, USA, 1993.

20. Porter, M.E. The Competitive Advantage of Nations; Macmillan Press: London, UK, 1998.

21. Patanakul, P.; Pinto, J.K. Examining the roles of government policy on innovation. J. High Technol. Manag. Res. 2014, 25, 97-107. [CrossRef]

22. Westhead, P.; Storey, D.J. Links between higher education institutions and high technology firms. Omega 1995, 23, 345-360. [CrossRef]

23. Sexton, M.; Barrett, P. A literature synthesis of innovation in small construction forms: Insights, ambiguities and questions. Constr. Manag. Econ. 2003, 21, 613-622. [CrossRef]

24. Dickson, K.E.; Hadjimanolis, A. Innovation and networking amongst small manufacturing firms in Cyprus. Int. J. Entrep. Behav. Res. 1998, 4, 5-17. [CrossRef]

25. Becheikh, N.; Landry, R.; Amara, N. Lessons from innovation empirical studies in the manufacturing sector: A systematic review of the literature from 1993-2003. Technovation 2006, 26, 644-664. [CrossRef]

26. Cohen, W.M.; Levinthal, D.A. Absorptive capacity: A new perspective on learning and innovation. Adm. Sci Q. 1990, 128-152. [CrossRef]

27. Oerlemans, L.A.; Meeus, M.T.; Boekema, F.W. Firm clustering and innovation: Determinants and effects. Pap. Reg. Sci. 2001, 80, 337-356. [CrossRef]

28. Ray, G.; Barney, J.B.; Muhanna, W.A. Capabilities, business processes, and competitive advantage: Choosing the dependent variable in empirical tests of the resource-based view. Strat. Manag. J. 2004, 25, $23-37$. [CrossRef]

29. Storto, C.L. Small group problem-solving and knowledge creation: A fuzzy cognitive maps investigation. Adv. Sci. Lett. 2016, 22, 1282-1286. [CrossRef]

30. Freel, M.S. Sectoral patterns of small firm innovation, networking and proximity. Res. Policy 2003, 32, 751-770. [CrossRef]

31. Rothwell, R.; Dodgson, M. External linkages and innovation in small and medium-sized enterprises. R D Manag. 1991, 21, 125-138. [CrossRef]

32. Bellini, E.; Storto, C.L. Growth strategy as practice in small firm as knowledge structure. Int. J. Knowl. Manag. Stud. 2006, 1, 133-159. [CrossRef]

33. Kogut, B.; Zander, U. Knowledge of the firm, combinative capabilities, and the replication of technology. Org. Sci. 1992, 3, 383-397. [CrossRef]

34. Barney, J. Firm resources and sustained competitive advantage. J. Manag. 1991, 17, 99-120. [CrossRef]

35. Harris, R.; Trainor, M. Innovations and R\&D in Northern Ireland manufacturing: A Schumpeterian approach. Reg. Stud. 1995, 29, 593-604.

36. Love, J.H.; Ashcroft, B.; Dunlop, S. Corporate structure, ownership and the likelihood of innovation. Appl. Econ. 1996, 28, 737-746. [CrossRef]

37. Zachariadis, M. R\&D, innovation, and technological progress: A test of the Schumpeterian framework without scale effects. Can. J. Econ. 2003, 36, 566-586.

38. Bhattacharya, M.; Bloch, H. Determinants of innovation. Small Bus. Econ. 2004, 22, 155-162. [CrossRef]

39. Rogers, M. Networks, firm size and innovation. Small Bus. Econ. 2004, 22, 141-153. [CrossRef]

40. Simonen, J.; McCann, P. Firm innovation: The influence of R\&D cooperation and the geography of human capital inputs. J. Urban Econ. 2008, 64, 146-154.

41. Carvalho, L.; Costa, T.; Caiado, J. Determinants of innovation in a small open economy: A multidimensional perspective. J. Bus. Econ. Manag. 2013, 14, 583-600. [CrossRef]

42. Cohen, W.M.; Levinthal, D.A. Innovation and learning: The two faces of R\&D. Econ. J. 1989, 99, 569-596.

43. Cohen, W.M.; Klepper, S. The tradeoff between firm size and diversity in the pursuit of technological progress. Small Bus. Econ. 1992, 4, 1-14.

44. Raymond, L.; St-Pierre, J. R\&D as a determinant of innovation in manufacturing SMEs: An attempt at empirical clarification. Technovation 2010, 30, 48-56.

45. De Jong, J.P.; Vermeulen, P.A. Determinants of product innovation in small firms: A comparison across industries. Int. Small Bus. J. 2006, 24, 587-609. [CrossRef] 
46. Qian, G.; Li, L. Profitability of small and medium-sized enterprises in high-tech industries: The case of the biotechnology industry. Strateg. Manag. J. 2003, 24, 881-887. [CrossRef]

47. Wolff, J.A.; Pett, T.L. Small-firm performance: Modeling the role of product and process improvements. J. Small Bus. Manag. 2006, 44, 268-284. [CrossRef]

48. Baldwin, J.R.; Hanel, P. Innovation and Knowledge Creation in an Open Economy: Canadian Industry and International Implications; Cambridge University Press: Cambridge, UK, 2003.

49. Acs, Z.J.; Audretsch, D.B. Entrepreneurship, innovation and technological change. Found. Trends Entrep. 2005, 1, 149-195. [CrossRef]

50. Chesbrough, H. Open Innovation: The New Imperative for Creating and Profiting from Technology; Harvard Business School Press: Boston, MA, USA, 2003.

51. Zeng, S.X.; Xie, X.M.; Tam, C.M. Relationship between cooperation networks and innovation performance of SMEs. Technovation 2010, 30, 181-194. [CrossRef]

52. Maggioni, M.A.; Nosvelli, M.; Uberti, T.E. Space versus networks in the geography of innovation: A European analysis. Pap. Reg. Sci. 2007, 86, 471-493. [CrossRef]

53. Maggioni, M.A.; Uberti, T.E. Knowledge networks across Europe: Which distance matters? Ann. Reg. Sci. 2008, 43, 691-720. [CrossRef]

54. Mancinelli, S.; Mazzanti, M. Innovation, networking and complementarity: Evidence on SME performances for a local economic system in North-Eastern Italy. Ann. Reg. Sci. 2008, 43, 567-597. [CrossRef]

55. Hewitt-Dundas, N. Resource and capability constraints to innovation in small and large plants. Small Bus. Econ. 2006, 26, 257-277. [CrossRef]

56. Cumbers, A.; Mackinnon, D.; Chapman, K. Innovation, collaboration, and learning in regional clusters: A study of SMEs in the Aberdeen oil complex. Environ. Plan. A 2003, 35, 1689-1706. [CrossRef]

57. Brioschi, F.; Brioschi, M.S.; Cainelli, G. From the industrial district to the district group: An insight into the evolution of local capitalism in Italy. Reg. Stud. 2002, 36, 1037-1052. [CrossRef]

58. Nieto, M.J.; Santamaria, L. The importance of diverse collaborative networks for the novelty of product innovation. Technovation 2007, 27, 367-377. [CrossRef]

59. Haque, I. Trade, Technology and Competitiveness; World Bank: Washington, DC, USA, 1995.

60. Guan, J.C.; Mok, C.K.; Yam, R.C.; Chin, K.S.; Pun, K.F. Technology transfer and innovation performance: Evidence from Chinese firms. Technol. Forecast. Soc. Chang. 2006, 73, 666-678. [CrossRef]

61. Knight, G.A. Entrepreneurship and strategy in the international SME. J. Int. Manag. 2001, 7, $155-171$. [CrossRef]

62. Svetina, A.C.; Prodan, I. How internal and external sources of knowledge contribute to firms' innovation performance. Manag. Glob. Transit. 2008, 6, 277-299.

63. Van Gils, A.; Zwart, P. Knowledge acquisition and learning in Dutch and Belgian SMEs: The role of strategic alliances. Eur. Manag. J. 2004, 22, 685-692. [CrossRef]

64. Sadler-Smith, E.; Spicer, D.P.; Chaston, I. Learning orientations and growth in smaller firms. Long Range Plan. 2001, 34, 139-158. [CrossRef]

65. Tidd, J.; Trewhella, M.J. Organizational and technological antecedents for knowledge acquisition and learning. R D Manag. 1997, 27, 359-375. [CrossRef]

66. Beaver, G.; Hutchings, K. Training and developing an age diverse workforce in SMEs: The need for a strategic approach. Educ. Train. 2005, 47, 592-604. [CrossRef]

67. Almeida, R.; Behrman, J.; Robalino, D. The Right Skills for the Job? Rethinking Training Policies for Workers; World Bank: Washington, DC, USA, 2012.

68. Ashford, N.A. An innovation-based strategy for a sustainable environment. In Innovation-Oriented Environmental Regulation: Theoretical Approach and Empirical Analysis; Hemmelskamp, J., Rennings, K., Leone, F., Eds.; Springer: New York, NY, USA, 2000; pp. 67-107.

69. Goh, A.L. Promoting innovation in aid of industrial development: The Singaporean experience. Int. J. Public Sect. Manag. 2005, 18, 216-240. [CrossRef]

70. Leitner, A.; Wehrmeyer, W.; France, C. The impact of regulation and policy or radical eco-innovation: The need for a new understanding. Manag. Res. Rev. 2010, 33, 1022-1041. [CrossRef]

71. The Organisation for Economic Co-operation and Development. Oslo Manual: Guidelines for Collecting and Interpreting Innovation Data; OECD Publishing: Paris, France, 2005. 
72. Freeman, C.; Soete, L. The Economics of Industrial Innovation; Routledge: London, UK; New York, NY, USA, 1997.

73. Acs, Z.J.; Anselin, L.; Varga, A. Patents and innovation counts as measures of regional production of new knowledge. Res. Policy 2002, 31, 1069-1085. [CrossRef]

74. Griliches, Z. Issues in assessing the contribution of research and development to productivity growth. Bell J. Econ. 1979, 92-116. [CrossRef]

75. Feldman, M.P.; Audretsch, D.B. Innovation in cities: Science-based diversity, specialization and localized competition. Eur. Econ. Rev. 1999, 43, 409-429. [CrossRef]

76. Acs, Z.J.; Audretsch, D.B. Patents as a measure of innovative activity. Kyklos 1989, 42, 171-180. [CrossRef]

77. Acs, Z.J.; Audretsch, D.B.; Feldman, M.P. Real effects of academic research: Comment. Am. Econ. Rev. 1992, 82, 363-367.

78. Rothwell, R. External networking and innovation in small and medium-sized manufacturing firms in Europe. Technovation 1991, 11, 93-112. [CrossRef]

79. Fritsch, M.; Meschede, M. Product innovation, process innovation, and size. Rev. Ind. Organ. 2001, 19, 335-350. [CrossRef]

80. Hall, B.H.; Lotti, F.; Mairesse, J. Innovation and productivity in SMEs: Empirical evidence for Italy. Small Bus. Econ. 2009, 33, 13-33. [CrossRef]

81. Audretsch, D.B.; Vivarelli, M. Firms size and R\&D spillovers: Evidence from Italy. Small Bus. Econ. 1996, 8, 249-258.

82. Vaona, A.; Pianta, M. Firm size and innovation in European manufacturing. Small Bus. Econ. 2008, 30, 283-299. [CrossRef]

83. Lee, S.; Park, G.; Yoon, B.; Park, J. Open innovation in SMEs: An intermediated network model. Res. Policy 2010, 39, 290-300. [CrossRef]

(C) 2017 by the authors. Licensee MDPI, Basel, Switzerland. This article is an open access article distributed under the terms and conditions of the Creative Commons Attribution (CC BY) license (http:// creativecommons.org/licenses/by/4.0/). 